\section{Rhamnose: Langanhaltender Anti-Falten- und Lifting-Effekt}

Das Anti-Aging-Molekül Rhamnose - ein mit 5\% oder 10\% hoch dosiertes, natürlich vorkommendes Zuckermolekül - erwies sich in der Entwicklung neuer Kosmetika am effektivsten, um auf die „papilläre Dermis" einzuwirken: Eine feine Zellschicht im oberen Teil der Dermis, die in der Lage ist, neue, junge Zellen in allen angrenzenden Hautschichten zu bilden und so die Regeneration der Haut zu unterstützen.

Im Laufe der Jahrzehnte verliert die Haut immer mehr an Elastizität und Festigkeit, Fältchen im Gesicht und am Hals werden dadurch deutlicher sichtbar. „Die Ursachen für diese Zeichen der Hautalterung sind Veränderungen in der Epidermis sowie der Dermis: Die Hautdicke nimmt mit zunehmenden Alter ab, wesentliche Bestandteile der Dermis wie kollagene und elastische Fasern, die für ein jugendliches Hautbild verantwortlich sind, werden abgebaut und die Zellregeneration lässt nach “, erläuterte Dr. Florence Benech, Chevilly-Larue, auf einem Symposium der Firma Vichy in Lissabon. „Untersuchungen zeigten, dass nur

\section{Nachwuchsphlebo- logen gefördert}

Drei Phlebologen erhielten im Rahmen der 53. Jahrestagung der Deutschen Gesellschaft für Phlebologie (DGP) in Berlin den Kreussler Phlebologists ' Travel Award, der regelmäßig im Rahmen des Kongresses zur Förderung des wissenschaftlichen Nachwuchses vergeben wird. Das mit jeweils 600 EUR dotierte Reise-Stipendium ermöglicht Phlebologen die Teilnahme an wichtigen Fachkongressen und die Präsentation ihrer wissenschaftlichen Arbeiten. Um sich für den Award zu qualifizieren, muss im Vorfeld eine wissenschaftliche Arbeit bei den Organisatoren des DGP-Kongresses eingereicht werden.

Nach Presseinformationen der Kreussler \& Co. $\mathrm{GmbH}$ die Fibroblasten der papillären Dermis auf die angrenzenden Hautschichten einwirken können. So hängt beispielsweise die Dicke der Oberhaut, die Dichte und Elastizität des Bindegewebsgeflecht und eine stärkere Verzahnung der Epidermis mit der Dermis vom Zustand und Anzahl der papillären Fibroblasten ab". Der Wirkstoff Rhamnose zeigte sich hier in der Aktivierung der "papillären“ Dermis besonders effektiv.

\section{Zucker zaubert Fältchen weg}

Eine gute Hautpflege für Menschen ab 40 sollte die Hydratation und das Strahlen der Haut erhöhen, feine Linien und
In den Wintermonaten empfiehlt es sich dringend, die richtige Hautpflege als Kälteschutz einzusetzen. Die duftstofffreie DERMASENCE Polaneth Lotion ist als spezielle Pflege bei trockener bis sehr trockener Haut, die zu Juckreiz neigt entwickelt worden.

Die Spezialpflege enthält Feuchtigkeitsfaktoren wie 4\% Urea und hochwertige Öle. Sie hydratisiert und pflegt die Haut intensiv und unterstützt die Regeneration, 3\% Polidocanol mindern Juckreiz. Die Hautbarriere wird stabilisiert und die Haut vor dem Austrocknen geschützt. Sie zieht schnell ein, ohne einen unangenehmen Film zu hinterlassen. Der Soforteffekt des enthaltenen Menthols kühlt die Haut und lenkt
Fältchen reduzieren und vor UV-Schäden schützen können. In der täglichen Praxis sei es wichtig, vorsichtig die Erwartungen der Patientinnen herauszufinden und das aktuelle Stadium der Hautalterung zu definieren, erklärte Dr. Anne Bouloc, Paris. Der klinische Benefit von Rhamnose konnte in vielfältigen Studien mit mehr als 400 asiatischen bzw. kaukasischen Frauen gezeigt werden. „Das neue LIFTACTIV SERUM 10 enthält Rhamnose in sehr hoher Konzentration: Ein Tropfen des 10\%-igen Serums zeigt bereits nach zehn Minuten seine Wirkung: Falten sind gemildert, die Haut ist deutlich glatter".

VICHY LIFTACTIV SERUM ist exklusiv in Apotheken erhältlich.

$(f v w)$

Quelle: Symposium "A new view on skin aging" anlässlich des EADV Annual Meeting, 21. Oktober 2011, Lissabon, Veranstalter: Vichy

\title{
Zertifizierte Pflege für trockene Haut mit Juckreizneigung
}

diese vom unangenehmen Juckreiz ab. Die Lotion reguliert bakterielles Wachstum und ist auch ideal als Pflege für die Altershaut.

Die DERMASENCE Polaneth Lotion wurde von der ICADA zertifiziert. Mit diesem Gütesiegel „functional cosmetic" wird bestätigt, dass die zertifizierten Produkte über physiologische Mechanismen kosmetische Wirkung entfalten, Hautkrankheits-Therapien unterstützen und Hauterkrankungen kurativ pflegen. Die Präparate werden durch unabhängige Sachverständige begutachtet und auf ihre Wirkung kontrolliert.

Nach Presseinformationen von P\&M

Cosmetics GmbH \& Co. KG 